\title{
部材せい設計変数を考慮した鋼構造建築骨組の最小重量設計に関する研究 A STUDY ON MINIMUM WEIGHT DESIGN OF STEEL BUILDING FRAMES CONSIDERING MEMBER SECTION'S DEPTH DESIGN VARIABLES
}

\author{
澤田 樹一郎*, 周岩**, 松 尾 彰***, 中村雄 治**** \\ Kiichiro SAWADA, Yan ZHOU, Akira MATSUO \\ and Yuji NAKAMURA
}

\begin{abstract}
The minimum weight design problem of steel frames considering member section's depth design variables is described in this paper. The algorithm that separately executes member section's depth optimization and cross section optimization is presented. The relaxation method is used in combination optimization of the member section's depth, and the sequential linear programming (SLP) method is used in the cross section optimization. 5-story frame and 10-story frame are designed by the presented method, and these frames are compared with the frames designed by genetic algorithm.
\end{abstract}

Keywords : Minimum weight design, Member section's depth, Relaxation method, Sequential linear programming

最小重量設計、部材断面せい、緩和法、反復線形計画法

\section{1. 序}

鋼構造建築骨組の部材断面最適化に関する研究は、これまでに 数多く行われてきたが、それらの研究の多くは、問題の簡単化の ため、部材断面積を連続設計変数とし、その他の部材断面性能を 断面積の関数として近似する定式化を採用している 1)27)等。しか し、現実の構造設計の場では、施工性や建築計画面の観点から、 梁せいを制限したいことや柱せいを統一したいといった要求もあ り、既往の設計問題の定式化では、これらの要求にこたえること は難しいと考えられる。そこで、最近では、部材せい又は部材幅 を指定して最適設計を行った例もいくつか存在する。小坂ら ${ }^{3)}$ は、 部材せいを指定し、板厚を設計变数とした問題を取り扱っている。 松本ら ${ }^{4)}$ は、部材せいが同じ断面の部材断面性能間の近似式を算 出し、SLP 法(Sequential liner programming)を用いて部材せい を指定した最適設計問題を解いている。また、堤 ${ }^{5)}$ は、部材せい も独立な設計変数とした問題を取り扱っている。しかし、そこで は、柱せいあるいは梁せいがすべての部材で同一と仮定している。 本論文では、部材断面積だけでなく部材せいも独立な設計変数 とし、複数の部材せい設計変数の設定も可能な建築骨組の最小重 量設計手法が提案される。部材せいと断面積を同時に設計変数と
して取り扱って最適化する場合には、以下に述べるような問題が 生じることが予想される。

(1) 一部材内に複数の設計変数が存在するので、最適化問題の構 造が複雑となり局所解に陥りやすくなる。

（2）部材せいに応じて部材断面糟の上下限制約值が不連続に変わ ることを考慮することが難しい。

このような問題に対して、遗伝アルゴリズム (G A) を用いて離 散最適化することも方法の一つとして考えられるが、ここでは、 部材せいの最適化と部材断面の最適化を分離して実行するアルゴ リズムを提案する。まず、2 節では、部材せいが指定された建築 骨組の部材断面最適化問題の定式化とその解法が示される。3 節, 4 節では、2 節の方法と部材せいの組み合わせ最適化手法を併 用することにより、部材せいと部材断面を最適化する方法が示さ れる。なお、部材せいの組み合わせ最適化には、Relaxation method (緩和法) ${ }^{6)}$ が用いられる。また、部材断面の最適化にはSLP 法 1)7)が用いられる。5 節では、設計例として、静的荷重下における 許容応力度と弹性層間変形角を制約条件とした 5 層および 10 層の 鋼構造建築骨組が最小重量設計される。また、6 節で、GAによ る設計解とも比較し、本手法の有効性が検討される。
* 広島大学 助手 $\cdot$ 工修

** 広島大学 大学院生·工修

*** 広島大学 教授. 工博

**** 中村建築研究所 所長· Ph. D.
Research Assoc., Hiroshima Univ., M. Eng.

Graduate Student, Hiroshima Univ., M. Eng.

Prof., Hiroshima Univ., Dr. Eng.

Head, Nakamura Research Institute, Ph. D. 


\section{2. 部材せい指定最小重量設計問題の定式化と解法}

\section{1 部材断面性能間関係}

部材せいが指定された場合には、部材断面積 A、断面二次モーメ ントI、断面係数 Zの間に以下の関係式が近似的に成立する。

$$
I=\alpha_{I} A
$$

$$
Z=\alpha_{Z} A
$$

ここでは部材断面を製鉄メーカーの市販部材断面リストから選択 寸ることにすれば、倸数 $\alpha \mathrm{I} ， \alpha \mathrm{z}$ は、市販部材断面リストを各部材 せいごとにグループ分けし、最小自乗法を適用することにより表 1 のように得られる。例として部材せい $500 \mathrm{~mm}$ の角形鋼管および細 幅系列H形鋼の部材断面性能間関保を図 1 に示す。

表 1(A) 角形鋼管断面の倸数 $\alpha \mathrm{z}, \alpha_{\mathrm{I}}$

\begin{tabular}{|c|c|c|}
\hline 部材せい & $\alpha \mathrm{z}$ & $\alpha_{\mathrm{I}}$ \\
\hline $350 \mathrm{~mm}$ & 10.1 & 175 \\
\hline $400 \mathrm{~mm}$ & 11.4 & 227 \\
\hline $450 \mathrm{~mm}$ & 13.0 & 293 \\
\hline $500 \mathrm{~mm}$ & 14.7 & 367 \\
\hline
\end{tabular}

表 1(B) 細幅系列 H形断面の係数 $\alpha z, \alpha_{\text {I }}$

\begin{tabular}{|c|c|c|}
\hline 部材せい & $\alpha_{\mathrm{Z}}$ & $\alpha_{1}$ \\
\hline $500 \mathrm{~mm}$ & 17.6 & 440 \\
\hline $600 \mathrm{~mm}$ & 20.8 & 624 \\
\hline $700 \mathrm{~mm}$ & 23.9 & 836 \\
\hline $800 \mathrm{~mm}$ & 26.2 & 1050 \\
\hline
\end{tabular}

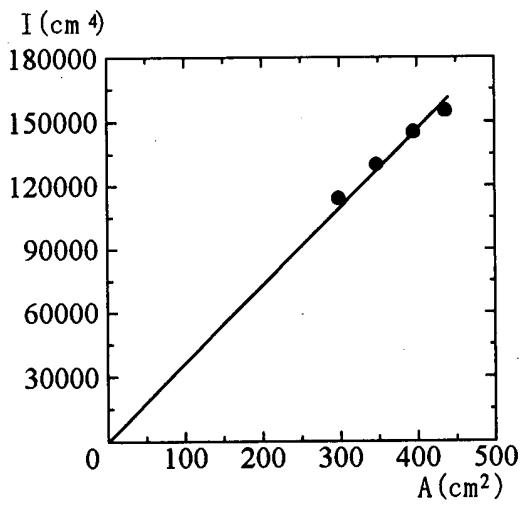

図 1(A) 部材せい $500 \mathrm{~mm}$ 角形鋼管の A-I 関係

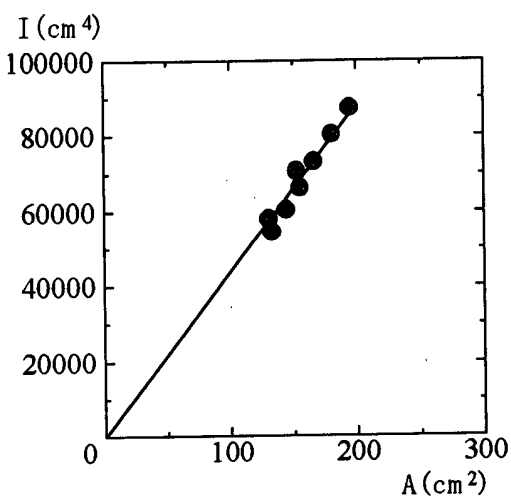

図 1(B) 部材せい $500 \mathrm{~mm}$ m細幅系列 H形鋼の A-I 関係

\section{2 部材せい指定最小重量設計問題の定式化}

部材応力および層間变形を制約条件とする多層多スパン鋼構造建 築骨組の部材せい指定最小重量弾性設計問題は、以下のように表現 できる。

Find $A_{i}(i=1,2, \ldots, m)$ which minimize structural weight,

$W=\rho \sum_{i=1}^{m} A_{i} L_{i}$

subjected to

$\left(\frac{N_{i}}{f_{N_{i}}}+\frac{M_{i}}{\alpha_{Z_{i}} f_{M_{i}}}\right) \cdot \frac{1}{A_{i}} \leq 1 \quad(i=1,2, \ldots, m)$

$\frac{\delta_{k+1}-\delta_{k}}{H_{k}} \leq \frac{1}{200} \quad\left(k=1,2, \ldots, n_{F}\right)$

$A_{L_{i}} \leq A_{i} \leq A_{U_{i}} \quad(i=1,2, \ldots, m)$

$D_{i}=\bar{D}_{i} \quad(i=1,2, \ldots, m)$

ここで、(7)式は、部材応力度に対する制約条件、(8)式は、層間 変形に対する制約条件、(9)式は、設計変数の上下限制約条件、(10) 式は、部材せい指定条件である。 $\rho$ は、鉄骨比重、 Li は、部材長、 $\mathrm{Ni}, \mathrm{Mi}$ は、部材 $\mathrm{i}$ の軸力、曲げモーメントの最大值、 $\mathrm{f}_{\mathrm{N} i}, \mathrm{f}_{\mathrm{M}} \mathrm{i}$ は、そ れぞれ軸力、曲げに対する許容応力度、 $\delta_{\mathbf{k}}, \mathrm{H}_{\mathbf{k}}$ は、それぞれ $\mathrm{k}$ 階の 水平変位と階高である。 $\mathrm{n}_{\mathrm{F}}, \mathrm{m}$ は、建築物の階数および部材総数であ る。A $A_{L}, A_{U}$ i は、設計変数 $A_{i}$ の上下限制約值であり、市販の部材断 面リストの情報と部材せい $\mathrm{D}_{\mathbf{i}}$ の指定值 $\overline{\mathrm{D}_{\mathrm{i}}}$ に応じて異なる值として 決定される。

\section{3 SLP 法 ${ }^{137)}$}

2.2 節で表した最小重量設計問題は、非線形制約条件付き最小化 問題であり、以下のようにも表せる。

Find $A=\left(A_{1}, A_{2}, \ldots, A_{m}\right)$ which minimize $W$

subjected to

$$
\begin{aligned}
& g_{j} \leq 1 \quad\left(j=1,2, \ldots, n_{R}\right) \\
& A_{L_{i}} \leq A_{i} \leq A_{U_{i}} \quad(i=1,2, \ldots, m)
\end{aligned}
$$

ここで、 $\mathrm{n}_{\mathrm{R}}$ は、制約条件の総数である。上記の問題の目的関数 $\mathrm{W}(\mathrm{A}) お よ ひ ゙$ 制約関数 $\mathrm{g}_{\mathrm{j}}$ を初期設計解 $\mathrm{A} 。$ まわりでテーラーー次近似 することにより、以下のような近似線形計画問題が作成できる。 
Find $A=\left(A_{1}, A_{2}, \ldots, A_{m}\right)$ which minimize

$\widetilde{W}=\left.\sum_{i=1}^{m} \frac{\partial W}{\partial A_{i}}\right|_{A=A_{o}}\left(A_{i}-A o_{i}\right)$

subjected to

$\tilde{g}_{j}=\left.\sum_{i=1}^{m} \frac{\partial g_{j}}{\partial A_{i}}\right|_{A=A_{o}}\left(A_{i}-A o_{i}\right) \leq 1 \quad\left(j=1,2, \ldots, n_{R}\right)$

$A_{L_{i}} \leq A_{i} \leq A_{U_{i}} \quad(i=1,2, \ldots, m)$

上述の近似線形計画問題は、シンプレックス法により容易に解く ことができる。SLP法は、このようなテーラー一次近似による近似 線形計画問題の作成とシンプレックス法の適用を絽り返すことによ り、設計解を改善していき、最適解を得る方法である。一般的には、 初期設計解が、制約条件の境界面から大きく離れている場合、テー ラーー次近似の誤差が大きくなるため、近似線形計画問題に設計変 数の変動幅 (move limit) を設ける。本論文の move limit の用い方 および感度係数（ $\partial g_{j} / \partial A_{i}$ など）の計算方法は、概ね文献 7) と同 じである。また、収束判定条件は、目的関数の変更量が、0.1\%以下 であり、かつすべての制約条件が $0.4 \%$ 許容誤差の範囲内で満足 することとしている7。

3. 部材せいの組み合わせ最適化

3.1 部材せいの組み合わせ最適化問題の定式化

2.節の部材せい指定最小重量設計手法を利用すれば、部材せいの 組み合わせ最適化問題は、以下のように表現できる。

Find $\bar{D}_{i}(i=1,2, \ldots, m)$ which minimize $W_{S L P}\left(\bar{D}_{1}, \bar{D}_{2}, \ldots, \bar{D}_{m}\right)$ $\bar{D}_{i} \in \begin{array}{lr}\left\{D c_{1}, D c_{2}, \ldots, D c_{n c}\right\} & (\text { Column member }) \\ \left\{D b_{1}, D b_{2}, \ldots, D b_{n b}\right\} & \text { (Beam member) }\end{array}$

ここで、 $W_{S L P}\left(\bar{D}_{1}, \bar{D}_{2}, \ldots, \bar{D}_{m}\right)$ は、2.節の部材せい指定最小重量 設計で得られる構造重量Wの值である。また、 $\mathrm{Dc}_{1}, \mathrm{Dc} \mathrm{c}_{2}, \ldots, \mathrm{Dc} \mathrm{c}_{\mathrm{nc}}$ ， $\mathrm{Db}_{1}, \mathrm{Db}_{2}, \ldots, \mathrm{Db} \mathrm{b}_{\mathbf{n b}}$ は、それぞれ柱せいおよび梁せいの離散候補であり、 この論文では、以下の值をとっている。

$\left\{D c_{1}, D c_{2}, \ldots, D c_{n c}\right\}=\{350 \mathrm{~mm}, 400 \mathrm{~mm}, 450 \mathrm{~mm}, 500 \mathrm{~mm}\}$

$\left\{D b_{1}, D b_{2}, \ldots, D b_{n b}\right\}=\{500 \mathrm{~mm}, 600 \mathrm{~mm}, 700 \mathrm{~mm}, 800 \mathrm{~mm}\}$

なお、柱せいおよび梁せいの值を制約したい場合には、その範囲 内における離散值を候補值とすればよい。

\section{2 Relaxation method (緩和法) $\left.{ }^{6}\right)$ に基づく組み合わせ最適化}

本論文では、 3.1 節の組み合わせ最適化問題を座標軸方向の直線 探索を反復する relaxation methodにより解くことにする。この方
法は、組み合わせ最適化問題よりむしろ連続設計变数の無制約最適 化問題に用いられることが多く、設計変数間の相関が小さく、かつ、 目的関数が単峰性の問題かあるいはそれに近い形の問題に対しては 有効と考えられる。Relaxation method に基づく探索法の概念図を 図 2 に示す。この図に示すように、探索する設計変数以外の設計変 数を固定し、目的関数を最小にする離散候補をすべての設計変数に 対して順次直線探索していく。直線探索には、ここで扱う問題にお ける離散候補数が少ないことから、離散候補 $\mathrm{Dc}_{1}$ あるいは $\mathrm{Db}_{1}$ から 探索を初めて、W 次の設計変数に対する探索を開始する手順としている。収束条件に ついては、すべての設計変数の探索が一巡するたびに設計解に変更 があったかを調へ、変更がないとき収束したと判定している。

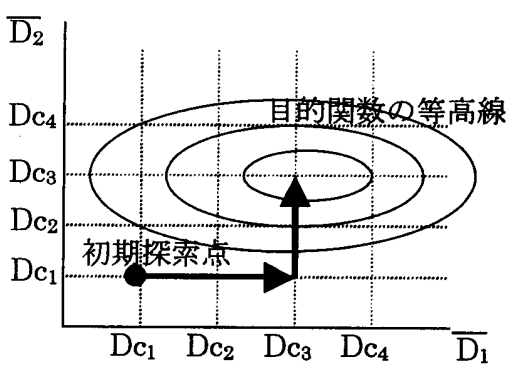

図 2 Relaxation method に基づく直線探索の概念図

\section{4. 最適設計のためのその他の計算処理}

4. 1 設計変数のグループ化

実際の設計の場では、施工上の理由から部材せいを統一したいこ とや部材断面を同じにしたいといった要求がある。本手法は、部材 せいと部材断面積を独立な設計変数としているので、このような要 求にも容易に答えることができる。ここでは、部材せい設計変数と 部材断面積設計変数を独立にグループ化できるようにしている。

\section{2 解なしに対する処理}

2.節の部材せい指定最小重量設計において、部材せいの指定値に よっては、それに対応する設計変数 $\mathrm{A}_{\mathrm{i}}$ の上限制約值 $\mathrm{Au}$ i が、必要 断面より小さくなることがあり、解なしとなる可能性がある。そこ で、このような場合には、(9)式の上限制約を取り除いて、2 節の最 小重量設計問題を解いた上で、目的関数(6)式を次式のようなペナル ティーを乗じた式に変更して、 $W_{S L P}\left(\bar{D}_{1}, \bar{D}_{2}, \ldots, \bar{D}_{m}\right)$ を求めること にしている。

$$
\begin{aligned}
& W=\rho \sum_{i=1}^{m} A_{i} L_{i}+\gamma \cdot \sum_{i=1}^{m} \Delta A_{i} \\
& \Delta A_{i}=\left\{\begin{array}{cc}
\frac{A_{i}}{A_{U_{i}}}-1 & \left(A_{i}>A_{U_{i}}\right) \\
0 & \left(A_{i} \leq A_{U_{i}}\right)
\end{array}\right.
\end{aligned}
$$

なお、(19)式の変数 $y$ については、6.3 節で後述されている。 


\section{5. 最小重量設計}

図 3 のような 5 層および 10 層の鋼構造純ラーメン骨組の設計例 を示す。荷重条件は、鉛直荷重（長期）のみと鉛直荷重十水平荷重

（短期）の二つの荷重条件を想定している。水平荷重の層せん断力 分布は、 $\mathrm{Ai}$ 分布に従っている。部材断面積設計変数は、図 4 の記 号のようにグループ化されている。また、 5 層骨組の部材せい設計 変数は、中柱、外柱、各層梁でそれぞれグループ化され、10 層骨組 では、梁の部材せい設計変数が 2 層単位でグループ化されている。 従って、独立な断面積設計変数の総数は、5 層骨組で 9、10 層骨組 で 13 となり、独立な部材せい設計変数の総数は、 5 層骨組、10 層 骨組とも 7 となる。表 2 は、得られた設計解を示している。D は、 部材せい、A は、断面樌、I は断面二次モーメント、Z は断面係数、 $\mathrm{W}$ は粠造重量、NLP は解が得られるまでのシンプレックス法の繰り 返し回数である。Relaxation methodによる組み合わせ最適化では、 設計変数の探索が 2 順目となったところで既に設計変更はなく、極 めて高い収束性を示した。なお、計算時間は、pentium $300 \mathrm{MHz}$ の パソコンで 30 秒程度である。

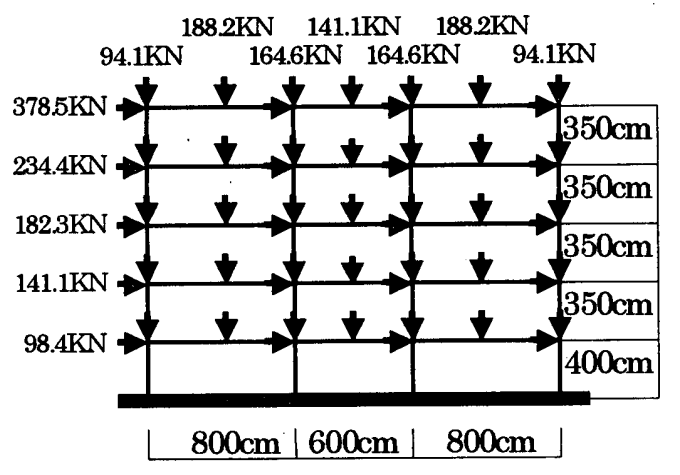

図 $3(A)$ 設計骨組（5 層骨組）

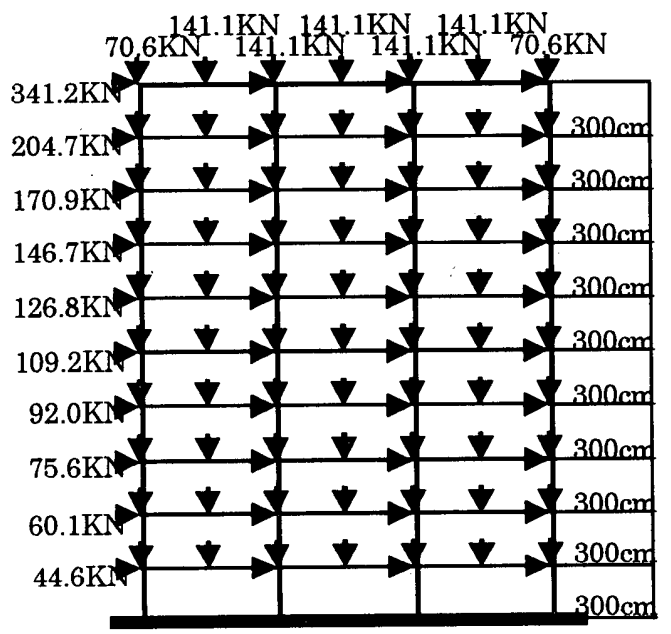

$600 \mathrm{~cm}+600 \mathrm{~cm}+600 \mathrm{~cm}$

図 3 (B) 設計骨組（10 層骨組）

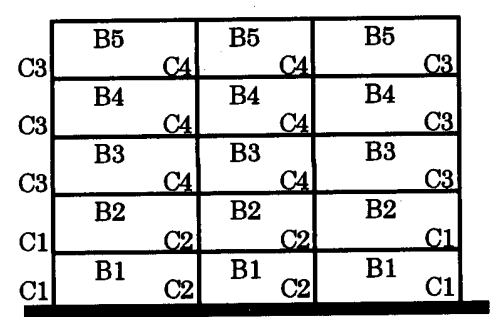

図 4 (A) 部材記号（5 層骨組）

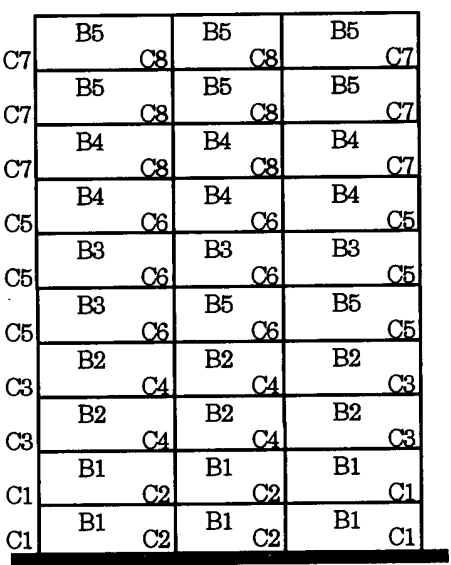

図 4 (B) 部材記号（10 層骨組）

表 $2(\mathrm{~A})$ 設計解（5 層骨組）

\begin{tabular}{|c|c|c|c|c|}
\hline & $\mathrm{D}(\mathrm{cm})$ & $\mathrm{A}\left(\mathrm{cm}^{2}\right)$ & $\mathrm{I}\left(\mathrm{cm}^{4}\right)$ & $\mathrm{Z}\left(\mathrm{cm}^{3}\right)$ \\
\hline $\mathrm{C} 1$ & 35.0 & 159 & 27800 & 1600 \\
\hline $\mathrm{C} 2$ & 50.0 & 299 & 110000 & 4380 \\
\hline $\mathrm{C} 3$ & 35.0 & 159 & 27800 & 1600 \\
\hline $\mathrm{C} 4$ & 50.0 & 299 & 110000 & 4380 \\
\hline B1 & 60.0 & 154 & 96000 & 3200 \\
\hline B2 & 60.0 & 159 & 99400 & 3310 \\
\hline B3 & 50.0 & 131 & 57400 & 2300 \\
\hline B4 & 50.0 & 131 & 57400 & 2300 \\
\hline B5 & 50.0 & 131 & 57400. & 2300 \\
\hline W & $25.1 \mathrm{t}$ & $\mathrm{N}_{\mathrm{LP}}$ & 166 & \\
\hline
\end{tabular}

表 2 (B) 設計解（10 層骨組）

\begin{tabular}{|c|c|c|c|c|}
\hline & $\mathrm{D}(\mathrm{cm})$ & $\mathrm{A}\left(\mathrm{cm}^{2}\right)$ & $\mathrm{I}\left(\mathrm{cm}^{4}\right)$ & $\mathrm{Z}\left(\mathrm{cm}^{3}\right)$ \\
\hline $\mathrm{C} 1$ & 35.0 & 221 & 38700 & 2230 \\
\hline $\mathrm{C} 2$ & 45.0 & 316 & 92600 & 4110 \\
\hline $\mathrm{C} 3$ & 35.0 & 206 & 36100 & 2080 \\
\hline $\mathrm{C} 4$ & 45.0 & 313 & 91500 & 4060 \\
\hline C5 & 35.0 & 159 & 27800 & 1600 \\
\hline C6 & 45.0 & 267 & 78100 & 3470 \\
\hline C7 & 35.0 & 159 & 27800 & 1600 \\
\hline C8 & 45.0 & 267 & 78100 & 3470 \\
\hline B1 & 60.0 & 161 & 100000 & 3340 \\
\hline B2 & 60.0 & 169 & 106000 & 3520 \\
\hline B3 & 60.0 & 145 & 90500 & 3010 \\
\hline B4 & 50.0 & 131 & 57400 & 2300 \\
\hline B5 & 50.0 & 131 & 57400 & 2300 \\
\hline W & $42.8 \mathrm{t}$ & N LP 200 & & \\
\hline
\end{tabular}


表 3 は、表 2 の連続設計解をもとにして、離散断面を選定した結 果を示している。この離散化は、表 2 の連続設計解を出発点として、 一番目の設計変数から順に、すべての制約条件を满足しかつ最小の 断面積を有する離散断面に変換していくことで実現できる。断面積 の連続設計解からの構造重量の増加は、両方の例とも $1 \%$ 以下であ りわずかであった。表 4 および表 5 は、表 3 の設計の応力度比およ び層間変形角をそれぞれ表している。この表から、すべての制約条 件が满足されていることが分かる。全般的に層間変形角に対する制 約が支配的だが、10 層骨組の下層柱では、部材応力度が制約值に近 い値となっている。なお、上層の梁は、最小断面積に対寸る制約で 決定されている。

表 $3(\mathrm{~A})$ 離散断面 (5 層骨組)

\begin{tabular}{|c|c|c|c|}
\hline & 部材断面寸法 & & 部材断面寸法 \\
\hline $\mathrm{C} 1$ & $\square 350 \times 12$ & B1 & H $600 \times 200 \times 12 \times 22$ \\
\hline $\mathrm{C} 2$ & $\square 500 \times 16$ & $\mathrm{~B} 2$ & $\mathrm{H} 600 \times 250 \times 12 \times 19$ \\
\hline C3 & $\square 350 \times 12$ & B3 & H $500 \times 200 \times 9 \times 22$ \\
\hline $\mathrm{C} 4$ & $\square 500 \times 16$ & $\mathrm{~B} 4$ & H $500 \times 200 \times 9 \times 22$ \\
\hline & & B5 & $\mathrm{H} 500 \times 200 \times 9 \times 22$ \\
\hline $\mathrm{W}$ & $25.2 \mathrm{t}$ & & \\
\hline
\end{tabular}

表 3 (B) 離散断面（10 層骨組）

\begin{tabular}{|c|c|c|c|}
\hline & 部材断面寸法 & & 部材断面寸法 \\
\hline $\mathrm{C} 1$ & $\square 350 \times 19$ & $\mathrm{~B} 1$ & $\mathrm{H} 600 \times 250 \times 12 \times 19$ \\
\hline $\mathrm{C} 2$ & $\square 450 \times 19$ & $\mathrm{~B} 2$ & $\mathrm{H} 600 \times 250 \times 12 \times 22$ \\
\hline $\mathrm{C} 3$ & $\square 350 \times 16$ & B3 & $\mathrm{H} 600 \times 200 \times 12 \times 19$ \\
\hline $\mathrm{C} 4$ & $\square 450 \times 19$ & B4 & $\mathrm{H} 500 \times 200 \times 9 \times 22$ \\
\hline C5 & $\square 350 \times 12$ & B5 & H500 $\times 200 \times 9 \times 22$ \\
\hline C6 & $\square 450 \times 16$ & & \\
\hline $\mathrm{C} 7$ & $\square 350 \times 12$ & & \\
\hline $\mathrm{C} 8$ & $\square 450 \times 16$ & & \\
\hline W & $43.1 \mathrm{t}$ & & \\
\hline
\end{tabular}

表 4 (A) 部材応力度比(5 層骨組)

\begin{tabular}{|c|c|c|c|c|c|}
\hline & 短期 & 長期 & & 短期 & 長期 \\
\hline C1 & 0.862 & 0.442 & B1 & 0.799 & 0.321 \\
\hline C2 & 0.894 & 0.325 & B2 & 0.720 & 0.291 \\
\hline C3 & 0.638 & 0.386 & B3 & 0.752 & 0.405 \\
\hline C4 & 0.493 & 0.224 & B4 & 0.604 & 0.415 \\
\hline \multicolumn{7}{|r|}{} & B5 & 0.460 & 0.426 \\
\hline
\end{tabular}

表 4 (B) 部材応力度比(10 層骨組)

\begin{tabular}{|c|c|c|c|c|c|}
\hline & 短期 & 長期 & & 短期 & 長期 \\
\hline C1 & 0.973 & 0.380 & B1 & 0.726 & 0.163 \\
\hline C3 & 0.997 & 0.448 & B2 & 0.658 & 0.150 \\
\hline C4 & 0.864 & 0.391 & B3 & 0.751 & 0.196 \\
\hline C5 & 0.870 & 0.369 & B4 & 0.692 & 0.227 \\
\hline C6 & 0.745 & 0.325 & B5 & 0.479 & 0.243 \\
\hline C7 & 0.550 & 0.285 & \multicolumn{3}{|c}{} \\
\cline { 1 - 2 } C8 & 0.463 & 0.171 & \multicolumn{3}{|c}{} \\
\cline { 1 - 2 }
\end{tabular}

表 $5(A)$ 層間変形角 $\left(\times 10^{-2}\right) \quad(5$ 層骨組 $)$

\begin{tabular}{|c|c|c|c|c|c|c|}
\hline 層 & 1 & 2 & 3 & 4 & 5 & 制約值 \\
\hline & 0.406 & 0.497 & 0.491 & 0.444 & 0.300 & 0.500 \\
\hline
\end{tabular}

表 $5(B)$ 層閒変形角 $\left(\times 10^{-2}\right) \quad(10$ 層骨組 $)$

\begin{tabular}{|c|c|c|c|c|c|c|}
\hline 層 & 1 & 2 & 3 & 4 & 5 & 制約值 \\
\hline & 0.337 & 0.496 & 0.495 & 0.466 & 0.496 & 0.500 \\
\hline 層 & 6 & 7 & 8 & 9 & 10 & 制約值 \\
\hline & 0.493 & 0.483 & 0.451 & 0.359 & 0.249 & 0.500 \\
\hline
\end{tabular}

\section{6. 遣伝アルゴリズムとの比較}

\section{1 遣伝アルゴリズム（GA)}

2 節 3 節で示された提案設計手法の有効性を検討するために、同 じ問題を遺伝アルゴリズムにより解き、設計解を比較する。GA の 選択交配には、文献 8)で示されているようなランク戦略が用いられ ている。また、エリート保存戦略が併用されている。交叉は一様交 叉とし、適応度の高い方の親の遺伝情報を $65 \%$ の確率で採用するこ とにしている。突然変異確率は $3 \%$ から $20 \%$ 、個体数は、20 から 150 の範囲で試行し最も良い設計解が得られたケースを示すことに している。

\section{2 部材せいの組み合わせ最適化問題における比較}

図 5 は、3.1の節の部材せいの組み合わせ最適化問題に対する $G$ $\mathrm{A}$ の世代数とその世代までに得られた最小重量設計解との関俰を示 している。適応度は、 $\mathrm{W}_{\mathrm{SLP}}\left(\overline{\mathrm{D}_{1}}, \overline{\mathrm{D}_{2}}, \ldots, \overline{\mathrm{D}}_{\mathrm{m}}\right)$ の值に基づいて評価してい る。表 6 は、GAにより得られた最小重量設計解およびその重量W、 設計解を得るまでのシンプレックス法の必要絽り返し回数 N $\mathrm{LP}_{\mathrm{PP}}$ を表

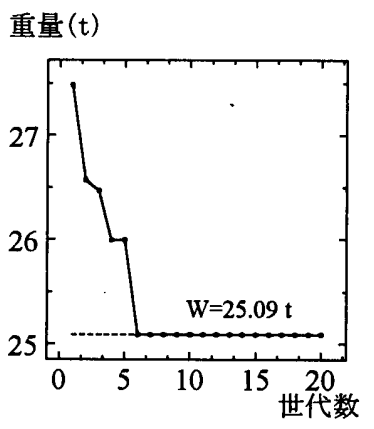

(A) 5 層骨組(個体数 25)

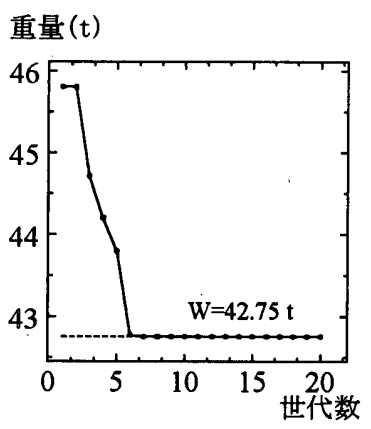

(B) 10 層骨組(個体数 40)
図 5 GA の収束過程

表 6 (A) GA による最小重量設計解（5 層骨組）

\begin{tabular}{|c|c|c|c|c|}
\hline & $\mathrm{D}(\mathrm{cm})$ & $\mathrm{A}\left(\mathrm{cm}^{2}\right)$ & $\mathrm{I}\left(\mathrm{cm}^{4}\right)$ & $\mathrm{Z}\left(\mathrm{cm}^{3}\right)$ \\
\hline $\mathrm{C} 1$ & 35.0 & 159 & 27800 & 1600 \\
\hline $\mathrm{C} 2$ & 50.0 & 299 & 110000 & 4380 \\
\hline $\mathrm{C} 3$ & 35.0 & 159 & 27800 & 1600 \\
\hline C4 & 50.0 & 299 & 110000 & 4380 \\
\hline B1 & 60.0 & 154 & 96000 & 3200 \\
\hline B2 & 60.0 & 159 & 99400 & 3310 \\
\hline B3 & 50.0 & 131 & 57400 & 2300 \\
\hline B4 & 50.0 & 131 & 57400 & 2300 \\
\hline B5 & 50.0 & 131 & 57400 & 2300 \\
\hline W & $25.1 \mathrm{t}$ & $\mathrm{N}_{\text {LP }} 1067$ & \\
\hline
\end{tabular}


している。GAによる設計解は、Relaxation method（表 2）とまっ たく一致していることがわかる。しかし、設計解を得るまでのシン プレックス法の繰り返し回数 NLP は、GA に比較して Relaxation method の方がかなり少ないことがわかる。

表 6 (B) GA による最小重量設計解（10 層骨組）

\begin{tabular}{|c|c|c|c|c|}
\hline & $\mathrm{D}(\mathrm{cm})$ & $\mathrm{A}\left(\mathrm{cm}^{2}\right)$ & $\mathrm{I}\left(\mathrm{cm}^{4}\right)$ & $\mathrm{Z}\left(\mathrm{cm}^{3}\right)$ \\
\hline $\mathrm{C} 1$ & 35.0 & 221 & 38700 & 2230 \\
\hline $\mathrm{C} 2$ & 45.0 & 316 & 92600 & 4110 \\
\hline $\mathrm{C} 3$ & 35.0 & 206 & 36100 & 2080 \\
\hline C4 & 45.0 & 313 & 91500 & 4060 \\
\hline C5 & 35.0 & 159 & 27800 & 1600 \\
\hline C6 & 45.0 & 267 & 78100 & 3470 \\
\hline C7 & 35.0 & 159 & 27800 & 1600 \\
\hline C8 & 45.0 & 267 & 78100 & 3470 \\
\hline B1 & 60.0 & 161 & 100000 & 3340 \\
\hline B2 & 60.0 & 169 & 106000 & 3520 \\
\hline B3 & 60.0 & 145 & 90500 & 3010 \\
\hline B4 & 50.0 & 131 & 57400 & 2300 \\
\hline B5 & 50.0 & 131 & 57400 & 2300 \\
\hline W & $42.8 \mathrm{t}$ & $\mathrm{N}_{\text {LP }}$ & 1342 & \\
\hline
\end{tabular}

\section{3 部材せい、部材断面の離散最適化問題における比較}

ここでは、GAを用いて部材せいおよび部材断面を同時に離散最 適化した結果を示す。なお、コーディングについては、部材せい設 計変数と部材断面設計変数を別々に番号付けし、バイナリコードに している。また、適応度は、構造重量に部材応力度および層間変形 角に対する制約条件 $\left(\mathrm{g}_{\mathrm{j}} \leqq 1\right)$ の満足度に関するぺナルティーを課した 次式 WPに基づき評価している。

$$
\begin{aligned}
& W_{P}=\rho \sum_{i=1}^{m} A_{i} L_{i}+\gamma \cdot \sum_{j=1}^{n_{R}} \Delta g_{j} \\
& \Delta g_{j}=\left\{\begin{array}{cc}
g_{j}-1 & \left(g_{j}>1\right) \\
0 & \left(g_{j} \leq 1\right)
\end{array}\right.
\end{aligned}
$$

(21)式および前述した 4.2 節の(19)式は、最小にすべき目的関数 （構造重量）にすべての制約条件あるいは特定の制約条件に関する ペナルティーを課すことにより、元の最適化問題（制約条件付き最 適化問題)を無制約化した式であると言える。これら二つの式には、 ペナルティー項に $\Delta \mathrm{g}_{\mathrm{j}}\left((19)\right.$ 式では、 $\left.\Delta \mathrm{A}_{\mathrm{i}}\right)$ の 1 乗和が含まれている。 このような 1 乗和のペナルティー関数は、 exact penalty function ${ }^{10)}$ と呼ばれ、連続設計変数の最適化問題では、一次微分倸数の連続性 は保証されないが、元の最適化問題の解とペナルティー関数による 解は、変数 $\gamma$ が有限値であっても厳密に一致する。しかし、本研究 のように離散設計変数が扱われる場合には、元の最適化問題とペナ ルティー関数による最適化問題は厳密には同等であるとは言えず、 制約条件が满足されない解が得られる可能性も否定できない。しか し、変数 $\gamma$ をある程度大きくとれば、制約条件が満足されない解を GA の個体群からある程度排除でき、さらに、制約条件をすべて満
足する固体群の中から最終的な解を選定することにより元の制約条 件付き最適化問題の解と同等の解が得られると期待できる。なお、 変数 $\gamma$ について、本研究では、目的関数の大きさに応じたぺナル ティーを課すために、次式のように目的関数值の係数倍としている。

$$
\gamma=\gamma_{C} \cdot \rho \sum_{i=1}^{m} A_{i} L_{i}
$$

係数 $\gamma \mathrm{c}$ は、小さすぎると前述の問題が生じるが、大きすぎる場 合にも、制約条件が満足されない領域のペナルティー関数の立ち上 がりが急勾配になり、最適解が得られにくい構造の問題となること が予想される。ここでは、幾例かの試行計算を行った結果、 $\gamma \mathrm{c}$ を 1.0 としている。また、 4.2 節(19)式の変数 $\gamma$ についても(23)式にお いて $\gamma_{\mathrm{C}}$ を 1.0 としたものを用いている。

図 6 は、GAの世代数とその世代までに得られた最小重量設計解 との関倸を示している。表 7 は、GAにより得られた離散断面であ

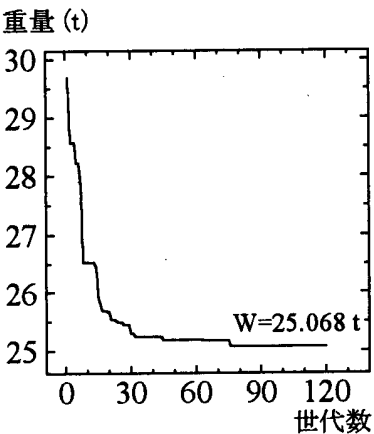

(A) 5 層骨組(個体数 80 )

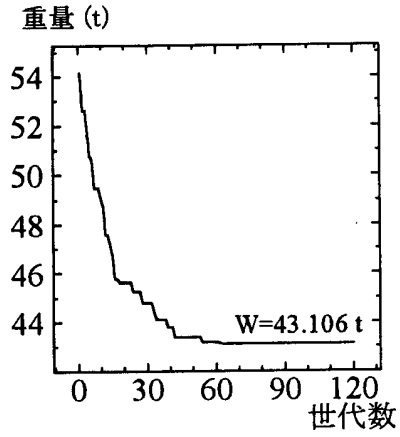

(B) 10 層骨組(個体数 150$)$

\begin{tabular}{|c|c|c|c|}
\hline & 部材断面寸法 & & 部材断面寸法 \\
\hline C1 & $\square 350 \times 12$ & $\mathrm{~B} 1$ & $\mathrm{H} 600 \times 250 \times 12 \times 19$ \\
\hline $\mathrm{C} 2$ & $\square 450 \times 16$ & $\mathrm{~B} 2$ & $\mathrm{H} 600 \times 300 \times 12 \times 22$ \\
\hline C3 & $\square 350 \times 12$ & B3 & $\mathrm{H} 500 \times 200 \times 9 \times 22$ \\
\hline $\mathrm{C} 4$ & $\square 450 \times 16$ & B4 & H500 $\times 200 \times 9 \times 22$ \\
\hline & & B5 & $\mathrm{H} 500 \times 200 \times 9 \times 22$ \\
\hline $\mathrm{W}$ & $25.1 \mathrm{t}$ & & \\
\hline
\end{tabular}

図 $6 \mathrm{GA}$ の収束過程

表 7 (A) G Aによる離散断面（5 層骨組）

\begin{tabular}{|c|c|c|c|}
\hline & 部材断面寸法 & & 部材断面寸法 \\
\hline $\mathrm{C} 1$ & $\square 350 \times 19$ & B1 & $\mathrm{H} 600 \times 250 \times 12 \times 22$ \\
\hline $\mathrm{C} 2$ & $\square 450 \times 19$ & $\mathrm{~B} 2$ & $\mathrm{H} 600 \times 250 \times 12 \times 22$ \\
\hline $\mathrm{C} 3$ & $\square 350 \times 16$ & B3 & $\mathrm{H} 600 \times 200 \times 12 \times 19$ \\
\hline $\mathrm{C} 4$ & $\square 450 \times 16$ & B4 & $\mathrm{H} 500 \times 200 \times 9 \times 22$ \\
\hline C5 & $\square 350 \times 12$ & B5 & $\mathrm{H} 500 \times 200 \times 9 \times 22$ \\
\hline C6 & $\square 450 \times 16$ & & \\
\hline $\mathrm{C} 7$ & $\square 350 \times 12$ & & \\
\hline $\mathrm{C} 8$ & $\square 450 \times 16$ & & \\
\hline W & $43.1 \mathrm{t}$ & & \\
\hline
\end{tabular}

表 7(B) G Aによる離散断面（10 層骨組） 
る。提案設計手法による離散断面（表 3）と一致しているわけでは ないが、両者の䅹造重量は、極めて近い值となっている。

\section{7. 結睔}

本論文では、部材断面積だけでなく部材せいも独立な設計変数と して考慮した鋼構造建築骨組の最小重量設計問題に対して、部材せ いの最適化と部材断面の最適化を分離して実行するアルゴリズムを 提案した。得られた知見を以下に示す。

（1）本提案手法では、複数の独立な部材せい設計変数を設定するこ とが可能であるため、部材せいの值を制限したり、他の部材と部材 せいを統一したりする条件を容易に考慮することができる。

(2) ここで取り扱った部材せいの組み合わせ最適化問題に对して、 relaxation method が非常に効率よく設計解を探索することが分か った。これは、この組み合わせ最適化問題の目的関数が単峰性かあ るいはそれに近い形の関数で、かつ部材せい設計变数間の相関が比 較的小さいためではないかと考えられる。

（3）GAを用いて部材せいおよび部材断面を同時に離散最適化した 結果と本提案設計手法による離散断面とを比較した。提案設計手法 による離散断面と G Aによるそれとは一致しているわけではないが、 両者の構造重量は、極めて近い值となっていることが確認された。

\section{参考文献}

1）田中尚，中村雄治：建築構造物の自動設計と最適設計，培風館，1973

2) 中村恒善 : 建筑骨組の最適䛯計、丸善、1980

3) 中村恒善、小坂郁夫:水平力を受ける弹性平面建筑骨組のひずみ制御設計、 日本建箱学会構造系論文報告集 No.363, pp.1 9, 1986.5

4）松本傎也、藤井大地、藤谷義信：梁せいを制約した鉄骨骨組構造の最小重 量設計、日本建築学会中国支部研究報告書、第 22 巻、pp.221 224、1999.3 5）堤和敏：部材断面成を同一とした鉄骨造せん断系弾性平面骨組の層間変形 角指定最小重量設計法、日本建筑学会構造工学諭文集、Vol.44B、pp.209 214、 1998.3

6）今野宏、山下宏 : 非線形計画法、日科技連、1994

7）澤田楖一郎、中村雄治、松尾彰：反復線形計画法を用いた平面ラーメンの 最適弹性·塑性設計法、日本建策学会構造系論文報告集、No.485、pp.117-126、 1996.7

8）大崎純 : 遺伝的アルゴリズム基つく不連続コスト関数を有する構造物の最 適設計法、日本建筑学会棧造系論文集、No.464、pp.119-127、1994.10 9）北野宏明：遺伝的アルゴリズム、産業図書、1993

10) G.L.Nemhauser, A.H.G. Rinnooy Kan, M.J.Todd : Handbooks in Operations Research and Management Science Vol.1 OPTIMIZATION, ELSEVIER SCIENCE PUBLISHERS B.V., 1989

\section{付表}

本研究で用いた部材断面リストを以下に表にして示す。
付表 1 角形鋼管断面の部材断面寸法

\begin{tabular}{|c|c|}
\hline 部材せい & 寸法 (mm) \\
\hline \multirow[t]{4}{*}{$350 \mathrm{~mm}$ 系列 } & $\square 350 \times 12$ \\
\hline & $\square 350 \times 16$ \\
\hline & $\square 350 \times 19$ \\
\hline & $\square 350 \times 22$ \\
\hline \multirow{4}{*}{$400 \mathrm{~mm}$ 系列 } & $\square 400 \times 16$ \\
\hline & $\square 400 \times 19$ \\
\hline & $\square 400 \times 22$ \\
\hline & $\square 400 \times 25$ \\
\hline \multirow{4}{*}{$450 \mathrm{~mm}$ 系列 } & $\square 450 \times 16$ \\
\hline & $\square 450 \times 19$ \\
\hline & $\square 450 \times 22$ \\
\hline & $\square 450 \times 25$ \\
\hline \multirow{4}{*}{$500 \mathrm{~mm}$ 系列 } & $\square 500 \times 16$ \\
\hline & $\square 500 \times 19$ \\
\hline & $\square 500 \times 22$ \\
\hline & $\square 500 \times 25$ \\
\hline
\end{tabular}

付表 2 細幅系列 $\mathrm{H}$ 形鋼（外法一定鋼）の部材断面寸法

\begin{tabular}{|c|c|}
\hline 部材せい & 寸法 (mm) \\
\hline \multirow{8}{*}{$500 \mathrm{~mm}$ 系列 } & $\mathrm{H} 500 \times 200 \times 9 \times 22$ \\
\hline & $\mathrm{H} 500 \times 200 \times 12 \times 19$ \\
\hline & $\mathrm{H} 500 \times 200 \times 12 \times 22$ \\
\hline & $\mathrm{H} 500 \times 200 \times 12 \times 25$ \\
\hline & $\mathrm{H} 500 \times 250 \times 9 \times 22$ \\
\hline & H500 $\times 250 \times 12 \times 22$ \\
\hline & $\mathrm{H} 500 \times 250 \times 12 \times 25$ \\
\hline & $\mathrm{H} 500 \times 250 \times 12 \times 28$ \\
\hline \multirow{15}{*}{$600 \mathrm{~mm}$ 系列 } & $\mathrm{H} 600 \times 200 \times 12 \times 19$ \\
\hline & $\mathrm{H} 600 \times 200 \times 12 \times 22$ \\
\hline & $\mathrm{H} 600 \times 200 \times 12 \times 25$ \\
\hline & $\mathrm{H} 600 \times 200 \times 12 \times 28$ \\
\hline & $\mathrm{H} 600 \times 250 \times 12 \times 19$ \\
\hline & $\mathrm{H} 600 \times 250 \times 12 \times 22$ \\
\hline & $\mathrm{H} 600 \times 250 \times 12 \times 25$ \\
\hline & $\mathrm{H} 600 \times 250 \times 12 \times 28$ \\
\hline & $\mathrm{H} 600 \times 250 \times 16 \times 28$ \\
\hline & $\mathrm{H} 600 \times 250 \times 16 \times 32$ \\
\hline & $\mathrm{H} 600 \times 300 \times 12 \times 22$ \\
\hline & $\mathrm{H} 600 \times 300 \times 12 \times 25$ \\
\hline & $\mathrm{H} 600 \times 300 \times 12 \times 28$ \\
\hline & $\mathrm{H} 600 \times 300 \times 16 \times 28$ \\
\hline & $\mathrm{H} 600 \times 300 \times 16 \times 32$ \\
\hline \multirow{5}{*}{$700 \mathrm{~mm}$ 系列 } & $\mathrm{H} 700 \times 250 \times 14 \times 25$ \\
\hline & $\mathrm{H} 700 \times 250 \times 14 \times 28$ \\
\hline & $\mathrm{H} 700 \times 300 \times 14 \times 25$ \\
\hline & $\mathrm{H} 700 \times 300 \times 14 \times 28$ \\
\hline & $\mathrm{H} 700 \times 300 \times 16 \times 28$ \\
\hline \multirow{6}{*}{ 800mm 系列 } & $\mathrm{H} 800 \times 250 \times 16 \times 25$ \\
\hline & $\mathrm{H} 800 \times 250 \times 16 \times 28$ \\
\hline & $\mathrm{H} 800 \times 300 \times 16 \times 22$ \\
\hline & $\mathrm{H} 800 \times 300 \times 16 \times 25$ \\
\hline & $\mathrm{H} 800 \times 300 \times 16 \times 28$ \\
\hline & $\mathrm{H} 800 \times 300 \times 16 \times 32$ \\
\hline
\end{tabular}

